\title{
Neuropsychological Principles of Activating the Speech of Children of the Senior Preschool age in the Course of Motor Actions
}

\section{Нейропсихологічні засади активізації мовлення дітей старшого дошкільного віку при виконанні рухових дій}

Nataliia Panhelova ${ }^{1}$

Dr. in Physical Education in Sport, Professor

\section{Наталія Пангелова ${ }^{1}$}

доктор наук з фізичного виховання та спорту, професор

E-mail: kafedra.tmfvis@ukr.net orcid.org./0000-0001-9133-0889

Tetiana Krutsevych ${ }^{2}$

Dr. in Physical Education in Sport, Professor

\section{Тетяна Круцевич ${ }^{2}$}

доктор наук з фізичного виховання та спорту, професор

E-mail: tmfv@ukr.net

orcid.org./0000-0002-4901-6148

${ }^{1}$ Pereiaslav-Khmelnytskyi

Hryhorii Skovoroda State

Pedagogical University

$\triangle$ 30, Sukhomlynskyi Str.,

Pereiaslav-Khmelnytskyi, Kyiv Reg.,

Ukraine, 08401

${ }^{2}$ National University of Physical

Education and Sport of Ukraine

$\triangle 1$, Fiskultura Str., Kyiv, Ukraine, 03150
${ }^{1} Д В Н 3$ «Переяслав-

Хмельницький державний педагогічний університет імені Григорія Сковороди» $\triangle$ вул. Сухомлинського, 30, м. Переяслав-Хмельницький, Київська обл., Україна, 08401

${ }^{2}$ Національний університет фізичного виховання i спорту України вул. Фізкультури, 1, м. Київ, Україна, 03150 
Original manuscript received July 04, 2018

Revised manuscript accepted March 25, 2019

\begin{abstract}
The investigation is devoted to the problem of speech development of children of the senior preschool age in the course of execution of motor actions that needed neuro-psychological basics of speech activation of children during motor actions. The results of the study indicate that preschool age is the most responsible period in the development of the personality of the person, its psychological and physical development, including the development of speech.

The presence of the interrelation of general and speech motility has been proved in the studies of I.P. Pavlov, A.M. Leontiev, A.R. Luria etc., which substantiates the position that the use of various motor actions contributes to solving the problems of speech development of the child. The presence of the relationship between intellectual, social, speech development and motor activity, the state of health of the child determines the feasibility of the use of such approaches, which involve an integrated influence to a child's personality. The exclusive role of physical and speech development determines the need for their integration for the general development of the child. The purpose of the integrated speech-motor joint motor activity is to ensure the interconnection of motor activity and development of speech of children of preschool age. The introduction of an integrated approach requires the use of innovative technologies (finger, articulation, respiratory gymnastics, footballgymnastics, logarithmics, etc.).

To test the effectiveness of the integrated speech-motor activity, a pedagogical experiment was conducted. After the survey, data was obtained that shows a positive dynamics in all indicators of speech.
\end{abstract}

Key words: neuro-psychological basics, integration, speech, motor activity, senior preschool children.

\title{
Вступ
}

Взаємозв'язок між рівнем сформованості компонентів мовлення й моторики дитини давно привертає увагу вчених (Выготский, 2003; Леонтьев, 1999; Ушакова \& Струнина, 2010; Colletta et al., 2018). Психофізіологи та нейрофізіологи розглядають мовлення як результат узгодженої діяльності різних ділянок (зон) головного мозку людини (Бернштейн, 1999; Бехтерев, 1999; Калмикова, 2016; Кольцова \& Рудина, 2004; Лурия, 2007). Виділяють сенсорний (сприйняття i розуміння мовлення) та моторний (говоріння, 
письмо) відділи головного мозку. Центр сенсорного мовлення (зона Верніке) породжує нервові зв'язки, завдяки яким звукосполучення 3 огляду на сенсорні відчуття утворюють слова. Центр моторного мовлення (зона Брока) регулює роботу артикуляторних органів, які продукують мовлення з безпосередньою участю в цьому процесі дихального апарату і м'язів черевного пресу.

Як зазначали В.М. Бехтєрєв (Бехтерев, 1999) та I.М. Сєченов (Сеченов, 1947), мовлення безпосередньо пов'язане 3 м'язовою моторикою, з рухами рук. Мовлення виникає в результаті узгодження функціонування головного мозку та інших відділів нервової системи. У здійсненні мовленнєвої функції беруть участь різні аналізатори: слуховий, кінестетичний, руховий і зоровий. Для того, щоб вимовити звук, дитині необхідно здійснити складний набір артикуляційних рухів. При цьому дихання, фонації та артикуляція повинні бути взаємопов'язані у своїй роботі, а мовленнєві рухи узгодженні з відповідними слуховими відчуттями. Для того, щоб дитина зрозуміла значення слова, необхідно поєднання між собою слухових, зорових і тактильних відчуттів у єдиний образ предмету (Пожиленко, 2006).

Наявність взаємозв'язку загальної та мовленнєвої моторики доведено в дослідженнях таких видатних вчених, як: І.П. Павлов (Павлов, 1951), О.М. Леонтьєв (Леонтьев, 1999), О.Р. Лурія (Лурия, 2007). Координація рухів розвивається тоді, коли дитина оволодіває руховими вміннями й навичками. Засвоєння рухових дій неможливе без участі мовлення. У свою чергу, чітке, активне виконання рухових дій для всього тіла вдосконалює рухи органів, які беруть участь в артикуляції (Мосалёва, 2014). На думку Н.В. Рижової (Рыжова, 2007) застосування різноманітних видів рухової діяльності сприяє мовленнєвому розвитку дитини: зв'язного мовлення, формування фонематичного слуху; чіткості артикуляції; зороворуховій координації.

Фізіологи зазначали на непересічному значенні м'язових відчуттів, які виникають під час артикуляції та передаються від органів мовлення до кори головного мозку. Формування звуків пов'язане із вдосконаленням діяльності периферійного мовленнєвого апарату. У дитини, яка своєчасно розвивається, засвоєння звукової складової мовлення відбувається одночасно із загальним фізичним розвитком (Павлов, 1951). 
Чимало досліджень свідчать про те, що рухова функція руки тісно пов'язана з функцією мовлення, сприяючи іiі вдосконаленню. Біля третини всієї площі рухової проекції головного мозку займає проекція кисті руки, яка розташована біля проекції мовленнєвої моторної зони. Це підтверджує, що тонка моторика (різноманітні рухи пальців кисті) стимулює дозрівання центральної нервової системи, що проявляється, зокрема, у пришвидшенні розвитку мовлення дитини (Бехтерев, 1999; Кольцова \& Рудина, 2004).

Важливе значення у становленні й формуванні особистості дитини має своєчасний фізичний розвиток, який $є$ підгрунтям успішної діяльності сукупності вищих психічних функцій. Забезпечення оптимального психомоторного розвитку дитини можливо лише в результаті цілеспрямованих впливів. Саме рухова активність розглядається сучасною психологічною наукою як особливий вид діяльності, що сприяє формуванню фізичних, моральних, інтелектуальних якостей, а також - розвитку психічних процесів і $є$ пов'язаним із цілісною, гармонійною особистістю та іiї здоров'ям.

Це положення підтверджується дослідженнями С.Л. Рубінштейна (Рубинштейн, 1999), О.В. Запорожця (Запорожец, 1981), Н.М. Анікєєвої (Аникеева, 1986), Л.І. Божович (Божович, 1995), Е.С. Вільчковського (Вильчковский, 1990), Дж. Волкер (Walker et al., 2006), Дж. Іверсон (Iverson, 2010) та ін.

Відомо, що в дошкільному віці біологічна потреба в русі $\epsilon$ провідною та актуалізує вплив на інтелектуальний, моральний та емоційний розвиток дитини, іiї звички та поведінку (Гальперин \& Кобыльницкая, 1974; Аркин, 1968; Богоявленская, 1987; Пангелова, 2014).

Дослідники відзначають наявність взаємозв'язку між інтелектуальним, мовленнєвим, соціальним розвитком і руховою діяльністю, фізичною підготовленістю, станом здоров'я дитини (Выготский, 2003; Венгер, 1988; Поддьяков, 2006; Рубинштейн, 1999 та ін.), що визначає доцільність застосування системи інтегрованого впливу на особистість дитини. Отже, провідна роль фізичного i мовленнєвого розвитку підростаючого покоління визначає необхідність їхньої інтеграції для загального розвитку дитини. 
Однак, дослідники (Вильчковский, 1990; Круцевич \& Пангелова, 2015; Москаленко, 2010) зауважують, що одним із кризових явищ вітчизняних традиційних i авторських систем $€$ розрив між рухами та іншими сторонами активності дітей дошкільного віку, відсутність реальних механізмів, які обумовлюють цілісність розвитку особистості дитини в процесі рухової діяльності. Окремі аспекти вирішення цієї проблеми розглядались у дослідженнях: А.А. Пивовара (Пивовар, 2005), яке було присвячено поєднаному розвитку фізичних i пізнавальних здібностей дітей 5-6 років в процесі рухової діяльності; В.В. Поліщука (Поліщук, 2008), який обгрунтував зміст занять 3 пріоритетним використанням елементів туризму зі старшими дошкільнятами для підвищення рівня їх фізичної підготовленості, розумового розвитку, мовлення i фізичного здоров'я.

Питання формування цілісної особистості дитини дошкільного віку, взаємозв'язок і взаємозалежність розвитку іï основних структурних компонентів у процесі рухової діяльності було предметом дослідження докторської дисертації Н.С. Пангелової (Пангелова, 2014). Що стосується питання розвитку мовлення дитини в процесі виконання рухових дій, то у доступній нам літературі є лише епізодичні відомості (Ядова, 2015; Вареник та ін., 2009), що і обумовлює актуальність нашого дослідження.

Мета - теоретично вивчити й емпірично обгрунтувати вплив рухової активності на мовленнєвий розвиток дітей старшого дошкільного віку.

\section{Методи та методики дослідження}

У проведених нами дослідженнях були застосовані наступні методи: а) теоретичні - аналіз психолінгвістичної, нейропсихологічної й нейролінгвістичної літератури; узагальнення та систематизація даних наукової літератури 3 проблематики дослідження; б) емпіричні - спостереження над мовленням i рухами дітей; експерименти (констатувальний, формувальний i контрольний); лінгвостатистичний метод, лінгвістичний аналіз, методи математичної статистики.

Також використовувалася психолінгводіагностична методика виявлення рівнів мовленнєвого розвитку дітей старшого 
дошкільного віку (Безрукова \& Каленкова, 2014). Сутність цієї методики полягає у тому, що вона дозволяє визначити рівень мовленнєвого розвитку дитини на основі кількісних та якісних показників. Методика складається 3 чотирьох блоків, кожен 3 яких містить тестові завдання. Блок 1 - мета тестових завдань полягала у визначенні обсягу словника та різноманітності зв'язків між лексичними одиницями (9 завдань). Блок 2 - мета тестових завдань блоку полягала у визначенні рівня граматичної компетенції. Основним критерієм іiі оцінки є сформованість словозамінних i словоутворювальних навичок та вмінь (9 завдань). Блок 3 - метою тестових завдань $\epsilon$ оцінка фонологічних навичок та вмінь. Ця оцінка визначається за результатами обстежень фонематичних процесів, навичок звукового аналізу і синтезу фонематичного оформлення мовлення (6 завдань). Метою завдань четвертого блоку є оцінка рівня сформованості зв'язного висловлювання у відповідності iз запропонованим сюжетом (4 завдання). Отримана інформація заносилася у зведений протокол обстеження мовлення дітей. Для розподілу дітей за рівнями розвитку мовлення користувались критеріально-рівневою шкалою (Безрукова \& Каленкова, 2014). Отже, критеріями визначення стану й рівнів розвитку мовлення дітей були, зокрема, такі: звукова культура мовлення (сприйняття мовлення, артикуляція, дикція, виразність мовлення); словесний запас (пасивний словник, активний словник); зв'язне мовлення (монологічне мовлення, діалогічне мовлення); граматична будова мовлення (морфологічна будова мовлення, синтаксична складова мовлення, словоутворення).

Дослідження проводилися в закладах дошкільної освіти № 9 «Сонечко» i № 10 «Любавонька» м. Переяслав-Хмельницького Київської області у 2016-2017 роках. Досліджуваним контингентом були дівчатка і хлопчики 5-го і 6-го років життя, вихованці закладів дошкільної освіти (далі - ЗДО) всього 157 дітей. Моніторинг мовленнєвого розвитку дітей відбувався за допомогою педагогічного колективу ЗДО і за письмовою згодою батьків.

\section{Результати теоретичного дослідження}

Аналіз даних літературних джерел (Выготский, 2003; Леонтьев, 1999; Лурия, 2007 та ін.) дозволяє стверджувати, що 
рухова активність сприяє розвитку мовлення, підвищенню розумової працездатності, формуванню довільних рухів і дій, які $є$ основою рухової поведінки людини. Як свідчать спеціальні дослідження у сфері психофізіології, саме прогрес у розвитку рухів (рухового аналізатору) у значній мірі визначає прогрес розвитку функцій мозку людини (Кольцова \& Рудина, 2004).

У науковій літературі представлені результати досліджень, які доводять філогенетичний зв'язок між розвитком рухів і формуванням мовлення. Взаємозв'язок загальної i мовленнєвої моторики вивчений і підтверджений кількома дослідженнями (Павлов, 1951; Сеченов, 1947; Лурия, 2007; Бехтерев, 1999; Кольцова \& Рудина, 2004 та ін.). Окремі розвідки свідчать про виняткову роль рухів, рухово-кінестетичного аналізатору в розвитку мовлення і мислення. Їх результати довели, що першою домінуючою уродженою формою діяльності є рухова. Крім того, якщо мовленнєвий розвиток дитини відбувається своєчасно і без ускладнень, то вона оволодіває системою мови одночасно 3 розвитком загальної моторики й диференційованими рухами рук, а порушення у засвоєнні мовлення у дітей тісно взаємопов'язані з недостатністю розвитку їх рухової системи у цілому (Бернштейн, 1991; Кольцова \& Рудина, 2004; Лурия, 2007; Павлов, 1951).

Одним з грунтовних положень, на які ми покликаємося $\epsilon$ теорія Н.О. Бернштейна (Бернштейн, 1991), яка свідчить про те, що мовлення є складним руховим актом, і як будь-який вид праксиса, він організований на різних рівнях головного мозку, на кожному 3 яких «обслуговуються» й інші види довільних рухів. Структури мозку, які беруть участь в організації довільних рухів людини, анатомічно представлені п'ятьма основними рівнями, які названі на зростаючій латинськими буквами А, B, C, D, Е. Окрім цього, кожен рівень організації рухів має назву, яка характеризує його анатомічний i функціональний радикал. Різним рівням мозкової організації рухових і вищих психічних функцій відповідають різні рівні мозкових структур. Кожний наступний рівень складніший за попередній за анатомічною будовою, вищий за функціональною ієрархією й молодший за філогенетичним віком. Безумовно, жодний рух не обслуговується тільки одним рівнем побудови, але для кожного руху є свій провідний рівень (Бернштейн, 1991). Так, на рівні «D» регулюються дії, які притаманні тільки людині. 
Ці дії забезпечуються великими півкулями головного мозку. Саме на цьому рівні забезпечується управління рухами артикуляційного апарату, тобто звуковимовою. Рівень «Е» - тут формується мотив рухового акту і здійснюється його основна корекція. На цьому рівні здійснюється керівництво не тільки мовленням (у подальшому письмом), але й різноманітним арсеналом хореографічних, імпровізаційних та інших інтелектуальних рухових дій.

У процесі онтогенетичного розвитку головного мозку людини відбувається посилення взаємодії між його півкулями, яке зумовлене прискоренням процесу мієлінізації нервових волокон мозолистого тіла. У дітей цьому процесу сприяє бімануальна координація, тобто цілеспрямовані та узгоджені рухи двома рухами. А така рухова дія, як повзання, окрім стимуляції моторних зон кори півкуль головного мозку, також сприяє покращенню взаємодії між ними. Узгоджені перехресні рухи рук і ніг (ліва рука - права нога), які регулюються протилежними півкулями мозку, сприяють розвитку асоціативних зв'язків і створюють умови для більш повної реалізації потенціалу мозку.

Повзання дитини дозволяе також розвивати тактильну чутливість. Завдяки інформації від пропріорецепторів, які надають інформацію про розташування частин тіла, у дитини формується просторова уява про власне тіло, яка має назву «схема тіла». Саме на етапі повзання закладається навичка орієнтації у просторі і формуються передумови для оволодіння складовими мовлення (Кольцова \& Рудина, 2004).

Проведенні дослідження (Медведева \& Яночкина, 2018) свідчать про те, що розвиток довільних рухів і становлення мовлення $є$ взаємопов'язаними процесами. Важливими факторами вдосконалення довільних рухів дошкільника $є$ гра i словесний супровід руху. Тільки в процесі гри рух стає повноцінним, а слово допомагає упорядкувати, сконструювати та організувати рухову дію.

Л.С. Виготський (Выготский, 2003), О.В. Запорожець (Запорожец, 1981) довели, що особистість розвивається в процесі діяльності, а для дитини провідною діяльністю $є$ гра. Ігрова діяльність проявляється у рухових діях, які супроводжують маніпуляції 3 іграшками, взаємодію 3 дорослими, дітьми. Чим різноманітнішими є рухи, які виконує дитина, тим більше інформації поступає у мозок, що, у свою чергу, інтенсифікує процес психічного 
розвитку дитини. Відповідність показників розвитку рухів дитини віковим нормативам свідчить про своєчасний нервово-психічний розвиток дитини.

Є.А. Аркін (Аркин, 1968), М.М. Кольцова, М.С. Рудіна (Кольцова \& Рудина, 2004) та ін. відмічають тісний взаємозв'язок між руховою та емоційною сферами, наголошуючи на тому, що відчуття, які виникають під час виконання рухів, є вкрай важливими для розвитку дитини. Виконання різноманітних рухів (повзання, ходьба, біг та ін.) викликає в дитини яскраві емоційні реакції. У зв'язку з цим, потреба дитини в руховій активності розглядається як одна 3 основних життєво необхідних потреб. Якщо необхідні умови для розвитку рухової сфери дитини відсутні, то в неї виникає емоційна млявість, що провокує відставання у нервово-психічному розвитку (у тому числі - і мовлення).

На розвиток вищої нервової діяльності безпосередній вплив здійснюють аферентні імпульси від пропріорицепторів, які виникають у результаті скорочення скелетних м'язів. Наприклад, на формування моторного мовлення здійснюють вплив рухів пальців рук; голосові реакції дітей раннього віку вдосконалюються під час виконання певних рухів. При цьому вплив пропріоцептивних імпульсів від м'язів рук на дозрівання кори великих півкуль $\epsilon$ суттєвим тільки у дошкільному віці, оскільки саме в цей період відбувається формування мовленнєвої моторної зони мозку.

Протягом перших років життя в дитини формується не тільки розуміння мовлення людей, які iї оточують, але й власне активне мовлення. Вчені, які вивчали діяльність мозку і психіку дітей, виявили взаємозв'язок між розвитком рухів і мовлення. Так, В.І. Гіляровський (Гиляровский, 1997) зазначав, що затримка розвитку мовлення відбувається, як правило, у результаті недорозвинення моторики дитини. О.В. Запорожець (Запорожец, 1981) указував, що довільні рухи дитини формуються за участю мовлення. С.М. Мастюкова (Мастюкова, 1992) виявила кореляційну залежність між динамікою розвитку моторики i мовлення на всіх етапах дошкільного дитинства. За результатами досліджень Т.П. Хризман, В.Д. Єремеєвої, Т.Д. Лоскутової (Хризман та ін., 1991) було виявлено, що під час виконання дитиною ритмічних рухів пальцями значно посилюється узгоджена діяльність скроневих та лобних відділів мозку. 
Таким чином, рухова активність дітей безпосередньо пов'язана 3 розвитком мовлення та комунікативною діяльністю. У процесі виконання рухових дій зміцнюється артикуляційний апарат дітей, розвивається фонематичний слух, формується культура мовлення. Дошкільнята вчаться дослухатися до слів, розрізняти складові частини слова, контролювати власне мовлення. Особливо важливим $€$ супровід рухів різноманітним мовним матеріалом. Промовляння віршів, скоромовок та ін. одночасно 3 виконанням рухів має низку переваг: мовлення ритмізується рухами, стає чітким та емоційним.

Установлено, що на формування мовлення впливає моторика дрібних м'язів кисті, координаційні здібності, функціональний стан дихальної системи, зорово-рухова координація. Неповноцінне мовлення негативно впливає на розвиток рухової сфери, особливо координаційних здібностей (Лурия, 2007).

Як вже зазначалося, розумовий i фізичний розвиток $\epsilon$ взаємопов'язаними процесами, що обумовлює доцільність застосування таких підходів, які забезпечують інтеграцію комунікативної й рухової діяльності. Н.В. Москаленко (Москаленко, 2010) зазначає, що інтегрування - це поєднання знань 3 різних освітніх сфер на засадах паритету й взаємодоповнення.

\section{Результати емпіричного дослідження}

В організації цього етапу дослідження ми виходимо 3 того, що передумовою інтеграції рухової та мовленнєвої діяльності $€$ спільність механізмів управління ними. Для перевірки ефективності запропонованого інтегрованого підходу був проведений експеримент, який відбувався у три етапи. Перший етап аналітичний, проведення моніторингу рівня розвитку мовлення дітей (вересень 2016 р.). Другий етап - упровадження технологій, спрямованих на інтеграцію мовленнєвого і фізичного розвитку дітей дошкільного віку в експериментальній групі (жовтень 2016 квітень 2017 рр.). Третій етап - контрольна діагностика розвитку мовлення дітей, виявлення динаміки іiі показників в контрольній та експериментальній групах (травень 2017 р.).

За підсумками діагностики на першому етапі були отримані результати, які представлені у таблиці 1. 
Нейропсихологічні засади активізації мовлення дітей старшого...

Таблиця 1. Розподіл дітей за рівнями розвитку мовлення, у \% (n=157)

\begin{tabular}{ccccc}
\hline Рівні & \multicolumn{4}{c}{ Критерії } \\
\hline & Зв'язне & Граматична & Словниковий & Звукова \\
мовлення & будова & ковльнняра & запас & мовлення \\
Високий & 10,21 & 40,11 & 50,21 & 59,62 \\
Середній & 30,32 & 30,15 & 30,17 & 40,38 \\
Низький & 59,47 & 29,74 & 19,62 & 0 \\
\hline
\end{tabular}

За висновками проведеної діагностики виявлено, що найбільш високі показники має звукова культура мовлення. Діти успішно виконали завдання на звуковимову, звуковий аналіз слів. Лексична складова мовлення на високому рівні сформована у 50,21\% дітей, на середньому - у 30,17\%, на низькому - у 19,62\%.

Під час обстеження рівня засвоєння синтагматичних зв'язків діти успішно добирали назви предметів на основі їх властивостей. При виконанні завдання підібрати слова, які визначають дії, називали наступні: дощ - iде; сонечко - світить, пече; півень співає, клює. Називали якості дій («Як стрибає коник?»- «Високо»).

У процесі виконання завдань для виявлення рівня сформованості навичок словотворення діти показали такі результати: добре утворювали слова 3 префіксами (сів - присів, плакав заплакав); не всі змогли виконати завдання щодо утворення слів 3 протилежним значенням (зібрав - розкидав і т. ін.); добре виконали завдання на добір слів зі значенням наближення/віддалення (кошеня прибігло, втекло і т. ін.); при виконанні завдань на утворення прикметників від іменників надавали тільки деякі правильні відповіді («пух» - «пухнастик», «дерево» - «дерев’яний» та ін.)

Під час дослідження зв'язного мовлення в дітей виникали значні труднощі у деяких завданнях - неправильно застосовували складні прийменники (задля, заради, з-за та ін.).

Таким чином, за результатами первинної діагностики виявлений низький рівень зв'язного мовлення в більшості дітей старшої групи $(59,47 \%)$, а також - низький рівень лексикограматичної складової мовлення.

Критерії оцінювання рівнів розвитку компонентів мовлення дітей старшого дошкільного віку представлені у таблиці 2. 
Таблиця 2. Критеріально-рівнева шкала розвитку мовлення дітей старшого дошкільного віку

\begin{tabular}{|c|c|c|c|}
\hline Критерії & \multicolumn{3}{|c|}{ Рівні } \\
\hline & Низький & Середній & Високий \\
\hline $\begin{array}{c}\text { Звукова } \\
\text { культура } \\
\text { мовлення }\end{array}$ & Порушення звуковимови & $\begin{array}{c}\text { Нестійке вимовляння } \\
\text { окремих звуків }\end{array}$ & Стійка чітка звуковимова \\
\hline $\begin{array}{c}\text { Словниковий } \\
\text { запас }\end{array}$ & $\begin{array}{l}\text { Обсяг пасивного словника } \\
\text { нижче припустимої } \\
\text { норми. Обсяг активного } \\
\text { словника нижче норми, } \\
\text { недоліки виявляються у } \\
\text { невірних назвах і у заміні } \\
\text { іменників і прийменників } \\
\text { з а м м н н и к а м и . } \\
\text { Спостерігаються значні } \\
\text { труднощі у підборі } \\
\text { слів подібного або } \\
\text { протилежного значення }\end{array}$ & 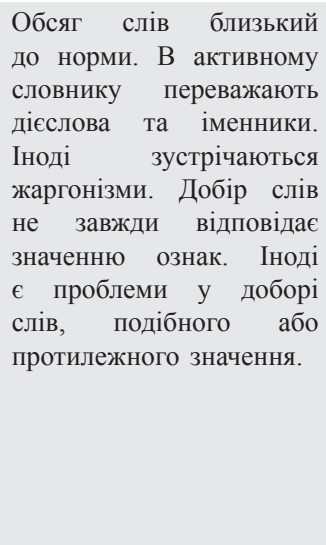 & 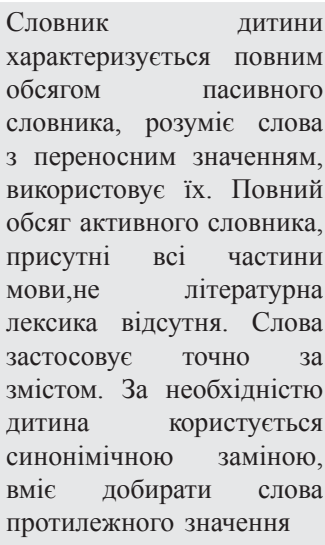 \\
\hline $\begin{array}{c}\text { Зв'язне } \\
\text { мовлення }\end{array}$ & $\begin{array}{lr}\text { Невірне } & \text { відтворення } \\
\text { тексту, } & \text { порушення } \\
\text { структури } & \text { тексту, } \\
\text { обмеженість } & \text { лексики, } \\
\text { необхідні підказки }\end{array}$ & $\begin{array}{lr}\text { Незначні } & \text { відхилення } \\
\text { від тексту; } & \text { відсутність } \\
\text { порушення } & \text { лексики; } \\
\text { переважання } & \text { простих } \\
\text { речень; } & \text { відсутність } \\
\text { тривалих пауз } & \end{array}$ & \begin{tabular}{lrr} 
Послідовна & i & точна \\
побудова & \multicolumn{2}{c}{ переказу; } \\
використання & авторських \\
слів і власних & точних \\
словесних & замін; \\
відсутність пауз &
\end{tabular} \\
\hline $\begin{array}{c}\text { Граматична } \\
\text { побудова } \\
\text { мовлення }\end{array}$ & $\begin{array}{l}\text { Переважають дієслова та } \\
\text { іменники; мала кількість } \\
\text { нових слів; відсутнє } \\
\text { вміння } \\
\text { утворювати намостійно } \\
\text { у мовленні плова; } \\
\text { велика кількість помилок, } \\
\text { які дитина не помічає; } \\
\begin{array}{l}\text { використовує } \\
\text { речення }\end{array}\end{array}$ & $\begin{array}{l}\text { У мовленні присутні } \\
\text { різні частини мови, але } \\
\text { дитина не дуже активно } \\
\text { ї застосовує; може } \\
\text { утворювати нові слова, } \\
\text { але є певні труднощі у } \\
\text { доборі суфіксів; часто } \\
\text { використовує прості } \\
\text { розповсюджені речення }\end{array}$ & 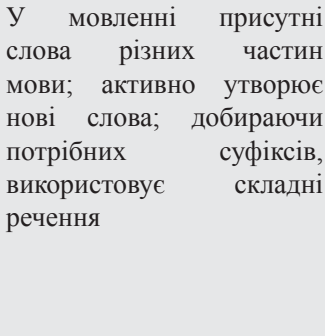 \\
\hline
\end{tabular}

На другому етапі експерименту відбувалося впровадження технологій, які сприяли інтеграції мовленнєвого і фізичного розвитку дітей дошкільного віку. Було створено дві групи дітей 5-6 років життя - контрольна (КГ) та експериментальна (ЕГ). КГ складалась із 79 дітей (ЗДО «Любавонька»), а ЕГ - із 78 дітей (ЗДО «Сонечко»). У контрольній групі всі організаційні форми занять із фізичної культури проводились згідно змісту оновленої програми навчання і виховання дітей дошкільного віку «Дитина». 
В експериментальній групі здійснювалася наступна робота: на другому етапі відбувалося впровадження інтегрованого підходу для розвитку психомоторики дитини, що потребувало застосування нових технологій, які зумовлені пошуком шляхів інтеграції мовленнєвої й рухової діяльності. До таких технологій відносимо різні види гімнастик (пальчикова, дихальна, артикуляційна, ритмічна, фітбол-гімнастика, сюжетно-рольова логоритмічна гімнастика), степаеробіка, вправи в сухому басейні.

Пальчикова гімнастика використовувалася для розвитку дрібної моторики, яка пов'язана 3 розвитком лівої скроневої й лівої лобної зони головного мозку. Пальчикові ігри спрямовувалися на формування комунікативних стосунків на рівні доторкання, емоційного переживання, контакту. Активізація дрібної моторики була зорієнтована на інтенсифікацію становлення мовлення, оскільки вербалізація мовлення дитини розпочинається тоді, коли рухи пальців рук стають більш точними.

Враховуючи те, що правильна вимова звуків забезпечується узгодженою роботою артикуляційного апарату (губ, язика, нижньої щелепи), нами використовувалися вправи, побудовані на рухах язика й щелепи для стимулювання роботи базального ганглія лімбічної системи, включаючи спеціалізовану ділянку - «чорну» субстанцію, яка поєднує базальний ганглій 3 лобною ділянкою мозку, що контролює мислення, мовлення й поведінку дитини. Такими були вправи з артикуляиійної гімнастики (Сомкова, 2012), використані 3 метою розвитку мовленнєвих звуків - фонем - для виправлення недоліків звукомовлення й рухливості артикуляційного апарату.

Процедура голосоутворення відбувалася за участю органів дихання (горло, бронхи, міжреберні м'язи та ін.). Будь-які види рухової діяльності використовувалися в експерименті для впливу на розвиток дихальної системи, але цілеспрямований вплив на іiі стан здійснювався за допомогою спеціалізованих фізичних вправ дихальної гімнастики.

У процесі організації рухової діяльності дітей в експерименті широке впровадження отримала ритмічна гімнастика (система рухів, яка тісно пов'язана 3 музичним супроводом). У процесі виконання рухів під музику регулювали процеси збудження i гальмування в центральній нервовій системі, стимулювався розвиток оперативної мовленнєвої пам'яті та уваги, нормалізувався емоційний 
стан дитини. Під час виконання комплексів ритмічної гімнастики діти вчилися виконувати вправи в конкретному темпі, узгоджували рухи й мовленнєві акти (підспівуючи в такт знайомій мелодії).

Гімнастика 3 використанням м'ячів-фітболів була одним 3 різновидів фітнес-гімнастики. М'ячі різної пружності, розмірів, ваги мають певні властивості, спроможні вирішувати завдання рухового та мовленнєвого характеру. За рахунок вібрації м'яча при виконанні вправ та завдяки амортизаційній функції м'яча активізувалися регенеративні процеси, покращувався кровообіг та мікродинаміка в міжхребцевих дисках, відбувалося розвантаження хребта, корекція його порушень. Вібрація м’яча разом із рухом посилювала імпульсацію пропріорецепторів, стимулюючи тим самим рухову зону кори головного мозку, що опосередковано позитивно актуалізувало й комунікативно-мовленнєві навички дитини.

В експерименті також впроваджувалася аеробіка - системи фізичних вправ, енергозабезпечення яких здійснювалося за умови присутності кисню. Для cmen-аеробіки добиралися вправи циклічного характеру (в основному ходьба), які виконувалися на степ-платформі (різні варіанти сходження на платформу, перестрибування через неї i т. ін.) 3 метою активізації процесів кровообігу, дихання і процесів метаболізму.

Вправи в «сухому» басейні (наповнення-кульки, паралон i т. ін.) застосовувалися для координації рухів і почуття рівноваги, а також збудження центрів усіх сенсорних систем, зокрема відчуття мови. Заняття в «сухому» басейні також спрямовувалися на позбавлення м’язової та емоційної напруженості, що є важливим для становлення мовлення і моторики дитини.

Особливе місце у вирішенні проблеми інтеграції рухової i мовленнєвої діяльності дитини відводилося сюжетно-рольовій логоритмічній гімнастиці. Ї̈̈ компоненти - рух, сюжет, музика, гра і слово, об’єднані в єдиний комплекс, створюють унікальні умови для розташованих поруч мовленнєвих i рухових центрів мозку. Оволодіння руховими вміннями й навичками сприяло розвитку загальної координації й тонкої довільної моторики та актуалізації мовленнєвих навичок.

Музичний супровід використовувався в експерименті для розвитку виразності, ритмічності рухів, розвитку рухового, мовленнєвого, слухового, зорового типів пам'яті, що, у свою 
чергу, впливало на інтонаційність мовлення. Тексти пісень, казок застосовувалися для розвитку функції аудіювання та запам'ятовування засобів виразного мовлення. Весь комплекс вправ із розвитку мовлення умовно поділявся на два компоненти: перший - спрямований на вдосконалення вимови, який включав у себе вимовляння звуків, промовляння речитативів та співання пісень; другий - спрямований на розвиток фонематичного сприйняття. До нього відносяться психолінгвістичні завдання, пов'язані 3 виділеннями звуків, прослуховування правильного мовлення. Завдання на активізацію мовлення, які виконувалися в узгодженні з рухом i музикою дозволяли поєднано впливати на різні аналізатори, які системно відповідають за комунікативномовленнєві й рухові акти.

Для визначення ефективності запропонованих підходів щодо інтеграції мовленнєво-рухової діяльності дітей дошкільного віку був проведений моніторинг (травень 2017 р.) їх мовленнєвого розвитку в контрольній та експериментальній групах.

Після обстеження були отримані відомості, які свідчать про позитивну динаміку в мовленнєвому розвитку дітей обох груп, але 3 різними темпами їх приросту. Діагностика відбувалася на основі методики, яка представлена вище. Результати наведені у таблиці 3.

Таблиця 3. Розподіл дітей контрольної та експериментальної груп за рівнями розвитку мовлення після експерименту, у \%

\begin{tabular}{cccc}
\hline \multirow{2}{*}{ Критерії } & Рівні & \multicolumn{3}{c}{ Групи } \\
& & $\begin{array}{c}\text { Контрольна } \\
(\mathrm{n}=79)\end{array}$ & $\begin{array}{c}\text { Експериментальна } \\
(\mathrm{n}=78)\end{array}$ \\
\hline \multirow{2}{*}{ Зв'язне мовлення } & Високий & 16,12 & 40,21 \\
& Середній & 60,11 & 48,11 \\
Граматична будова & Низький & 23,77 & 11,69 \\
мовлення & Високий & 43,07 & 51,11 \\
Словниковий & Середній & 30,05 & 38,01 \\
запас & Низький & 26,88 & 10,88 \\
& Високий & 52,01 & 63,01 \\
Звукова культура & Середній & 31,01 & 4,96 \\
мовлення & Низький & 16,98 & 72,12 \\
& Високий & 63,11 & 27,88 \\
\hline
\end{tabular}


Результати, представлені в таблиці свідчать, що найбільш високий результат в ЕГ був досягнутий за критеріями «Зв’язне мовлення», де високий рівень цього компоненту мовлення був зареєстрований у 40,21\% дітей $(+30 \%)$, середній - у 48,11\%, низький - в $11,69 \%(\mathrm{p} \leq 0,05)$. У контрольній групі також відбулося покращення, але тільки $16,12 \%$ дітей (+6\%) продемонстрували послідовну i точну побудову переказу, використання авторських слів, відсутність граматичних помилок, що свідчить про високий рівень зв'язного мовлення; 60,11\% дітей виявили середній рівень розвитку і $23,77 \%$ - низький $(\mathrm{p} \leq 0,05)$.

Аналізуючи такий структурний компонент мовлення як «граматична будова мовлення», було з'ясовано, що високий рівень розвитку цієї складової було виявлено у 51,11\% дітей ЕГ (+11\%) $(\mathrm{p} \leq 0,05)$ та у $43,07 \%$ дітей КГ $(+3 \%) \quad(\mathrm{p} \leq 0,05)$; середній рівень у $38,01 \%(\mathrm{p} \leq 0,05)$ дітей ЕГ і $30,05 \%(\mathrm{p} \leq 0,05)-К Г$, а низький $-\mathrm{y}$ $26,88 \%(p \leq 0,05)$ дітей КГ і тільки в $10,88 \%(p \leq 0,05)$ дітей ЕГ.

Визначаючи словниковий запас дітей досліджуваних груп було виявлено, що запропоновані підходи щодо інтеграції комунікативної й рухової діяльності дошкільників сприяли поповненню як пасивного обсягу словника (розуміє слова в переносному значенні i використовує їх у мовленні), так і активного обсягу (присутні всі частини мовлення, за необхідності дитина користується синонімічною заміною, вміє добирати слова протилежного значення). Такий високий рівень був виявлений у 63,01\% дітей ЕГ $(+13 \%)(\mathrm{p} \leq 0,05)$ і у $52,01 \%$ дітей КГ $(+2 \%)(\mathrm{p} \leq 0,05)$, середній рівень розвитку словникового запасу у дітей ЕГ і КГ був приблизно однаковим $(32,02 \%$ і $31,01 \%$ відповідно) $(\mathrm{p} \leq 0,05)$, а низький рівень у 4,96\% (p $\leq 0,05)$ дітей ЕГ і 16,98 (p $\leq 0,05)-$ КГ.

Результати формувального експерименту дозволили з'ясувати, що за таким критерієм як «звукова культура мовлення» стійка чітка звуковимова (високий рівень) була зафіксована у 72,12\% дітей ЕГ (+11\%) (p $\leq 0,05)$ і $63,11 \%$ дітей КГ $(+3 \%)(\mathrm{p} \leq 0,05)$, а середній у $27,88 \%(p \leq 0,05)$ дітей ЕГ та $36,89 \%(p \leq 0,05)$ дітей КГ. Низький рівень звуковимови в дітей досліджуваних груп відсутній.

Таким чином, темпи приросту за усіма показниками розвитку мовлення були достовірно вищими $(\mathrm{p} \leq 0,05)$ у дітей експериментальних груп у порівнянні 3 контрольними, що дає 
підстави стверджувати про позитивний вплив рухової активності дітей на мовленнєвий розвиток дітей старшого дошкільного віку.

\section{Висновки}

Отже, організація інтегративної комунікативно-рухової роботи 3 дітьми, спрямованої на забезпечення впливу рухів на розвиток мовлення старших дошкільнят ЕГ у ЗДО «Сонечко» довела правильність нейропсихологічних i нейролінгвістичних положень щодо активізації мовлення дітей при виконанні рухових дій, а також наше припущення, яке стосується взаємопов'язаного розвитку рухових і мовленнєвих актів у дітей.

Критеріями ефективності запропонованих підходів слугували динаміка рівнів розвитку таких складових мовлення: зв'язне мовлення, граматична будова мовлення, словниковий запас, звукова культура мовлення. Порівняння даних, які були отримані під час проведення формувального експерименту свідчать, що в експериментальній групі дітей 5-6 років спостерігаються значно вищі результати в розподілі дітей за рівнями розвитку компонентів мовлення $(\mathrm{p} \leq 0,05)$, ніж у дітей контрольної групи, що підтверджує доцільність використання запропонованих підходів.

Перспективи подальших досліджень полягають у розробці комплексу методичних матеріалів для поєднаного розвитку мовлення та фізичних здібностей дітей 4-6 років у процесі проведення різноманітних організаційних форм з фізичного виховання в умовах закладу дошкільної освіти (фізкультурне заняття, фізкультурнооздоровчі заходи в режимі дня, активний відпочинок).

\section{Література}

Аникеева Н.М. Гармония как понятие социального мышления. Ростов на Дону: Феникс, 1986. 111 с.

Аркин Е.А. Ребёнок в дошкольные годы. Москва: Просвещение, 1968. 475 с.

Безрукова О.А., Каленкова О.Н. Методика определения уровня речевого развития детей дошкольного возраста. Москва: Русская речь, 2014. 70 с.

Бернштейн Н.А. О ловкости и ее развитии. Москва: Физкультура и спорт, 1991. C. $111-171$.

Бехтерев В.М. Избранные труды по психологии личности: в 2 т. / под ред. С.Г. Никифорова, Л.А. Коростылевой. Санкт-Петербург: Питер, 1999. T. $2.427 \mathrm{c}$. 
Богоявленская Д.Б. Психологические основы интеллектуальной активности: автореф. дисс. ... докт. психол. наук. Москва, 1987. 49 с.

Божович Л.И. Избранные педагогические труды. Проблемы формирования личности. Москва: Междунар. пед. академ., 1995. 78 с.

Вареник Е.Н., Корлыханова 3.А., Китова Е.В. Физическое и речевое развитие дошкольников: взаимодействие учителя-логопеда и инструктора по физкультуре. Москва: ТН Сфера, 2009, 142 с.

Васюкова Н.Е., Чехонина О.И. Интеграция содержания образования через планирование педагогической деятельности. Детский сад от А до Я. 2004. Вып. 6(12). С. 8-14.

Венгер Л.А. Воспитание сенсорной культуры ребёнка. Москва: Просвещение, 1988. 234 с.

Вильчковский Э.С. Психолого-педагогические основы системы физического воспитания дошкольников. Воспитание детей дошкольного возраста: монография. Київ: Рад. школа, 1990. С. 319-364.

Выготский Л.С. Психология развития ребёнка. Москва: ЭКСМО, 2003. 507 с.

Гальперин П.Я., Кобыльницкая С.Л. Эксперементальное формирование внимания. Москва: Изд-во Москов-го ун-та, 1974. 95 с.

Гиляровский В.А. К вопросу о генезе заикания у маленьких детей и роли его для общего развития личности и его лечение: в 2 т. Москва: ВЛАДОС, 1997. T. 1. C. 75-97.

Запорожец А.В. Условия и движущие причины психического развития ребенка. Москва : Просвещение, 1981. С. 27-55.

Калмикова Л.О. Про стан розвитку мовлення як діяльності у дітей 5 років. Psycholinguistics. Психолінгвістика. Психолингвистика. 2016. Вип. 19(1). C. 84-97.

Кольцова М.М., Рудина М.С. Ребенок учится говорить. Пальчиковый игротренинг. Екатеринбург: У-Фактория, 2004. 224 с.

Круцевич Т.Ю., Пангелова Н.Є. Концептуальні засади гармонійного розвитку особистості дитини дошкільного віку в процесі фізичного виховання. Теорія $i$ методика фізичного виховання $і$ спорту. 2015. № 2. С. 106-115.

Леонтьев А.Н. Деятельность и личность. Самара: Изд. Дом «Бахрах», 1999. Т. 2. С. $165-188$.

Лурия А.Р. Основы нейропсихологии. Москва: Академия, 2007. 381 с.

Мастюкова Е.M. Ребенок с отклонениями в развитии: Ранняя диагностика и коррекция. Москва: Просвещение, 1992. 94 с.

Медведева Е.Ю., Яночкина П.А. Использование двигательных техник в работе по коррекции нарушений звукопроизношения у детей дошкольного возраста: нейропсихологический аспект. Перспективы науки и образования. 2018. № 2(32). С. 152-155.

Мосалёва Н.В. Интегрированные занятия по речевому и физическому развитию детей старшего дошкольного возраста. «Фестиваль педагогических идей». Открытый урок. 2014. Режим доступа: http:открытый урок.рф/статьи/59117

Москаленко Н.В. Теоретико-методичні засади інноваційних технологій в системі фізичного виховання молодших школярів: дис. ... д-ра наук 3 ф.в. і с.: 24.00.02. Дніпропетровськ, 2010. 454 с.

Павлов И.П. Полное собрание сочинений: в 4 т. Москва, 1951. Т. 3. 371 с.

Пангелова Н.С. Формування гармонійно розвиненої особистості дитини дошкільного віку в процесі фізичного виховання: дис. ... д-ра наук $з$ ф.в. i с.: 24.00.02. Переяслав-Хмельницький, 2014. 445 с. 
Пивовар А.А. Поєднаний розвиток фізичних і пізнавальних здібностей дітей 5 і 6 років у процесі фізичного виховання: дис. ... канд. наук 3 ф. в. і с.: 24.00.02. Переяслав-Хмельницький, 2005. 210 с.

Поддьяков Н.Н. Доминирование процессов интеграции - закон развития детей дошкольного возраста. Дошкольное воспитание. 2006. № 1. С. 73-77.

Пожиленко Е.А. Артикуляционная гимнастика по развитию моторики, дыхания и голоса у детей. Москва: Каро, 2006. 92 с.

Поліщук В.В. Розвиток рухових і розумових здібностей дітей 5-го і 6-го років життя в процесі фізичного виховання засобами дошкільного туризму: автореф. дис. ... канд. наук $з$ ф. в. і с.: 24.00.02. Львів, 2008. 21 с.

Прописнова Е.П. Интеграция двигательного и речового развития дошкольников (на основе сюжетно-ролевой логоритмической гимнастики). Начальная школа плюс до и после. 2006. № 7. С. 11-13.

Рубинштейн С.Л. Основы общей психологии. Санкт-Петербург: Питер Ком, 1999. $720 \mathrm{c}$.

Рыжова Н.В. Развитие речи в детском саду. Ярославль: Академия развития, 2007. 159 c.

Сеченов И.М. Избранные философские и психологические произведения. Москва, 1947. 445 c.

Сомкова О.Н. Новые подходы к организации работы по развитию речи детей дошкольного возраста. Детский сад: Теория и практика. 2012. № 3. С. 6-7.

Ушакова О.С., Струнина Е.М. Методика развития речи детей дошкольного возраста. Москва: Гуманит. изд. центр ВЛАДОС, 2010. 287 с.

Хризман Т.П., Еремеева В.Д., Лоскутова Т.Д. Эмоции, речь и активность мозга ребенка. Москва: Педагогика, 1991. 232 с.

Ядова Р.Х. Формирование речевой культуры младших дошкольников средствами физического воспитания: автореф. дисс. ... канд. пед. наук: 13.00.04. Майкоп, 2015. 21 с.

Colletta, J., Pellenq, C., Hadian-cefidekhanie, A., \& Rousset, I. (2018). Developmental changes in articulation rate and phonic groups during narration in French children aged four to eleven years. Journal of Child Language, 45(6), 1-20. https://doi. org/10.1017/S0305000918000235

Iverson, J. (2010). Developing language in a developing body: The relationship between motor development and language development. Journal of Child Language, 37(2), 229-261. https://doi.org/10.1017/S0305000909990432

Walker, J.F., \& Archibald, L.M. D. (2006). Articulation rate in preschool children: a 3-year longitudinal study. International Journal of Language and Communication Disorders, 41(5), 541-65. https://doi.org/10.1080/10428190500343043

\section{References}

Anykeeva, N.M. (1986). Garmoniya kak ponyatiye sotsialnoggo myshleniya [The harmony as a notion of social thinking]. Rostov on Don: Fenyks [in Russian].

Arkin, E.A. (1968). Rebyonok $v$ doshkolnye gody [The child in a pre-school age]. Moscow: Prosveshcheniye [in Russian].

Bezrukova, O.A., \& Kalenkova, O.N. (2014). Metodika opredelenija urovnja rechevogo razvitija detej doshkolnogo vozrasta [Methods for determining the level of speech development of children of preschool age]. Moscow: Russkaya rech [in Russian]. 
Bernshtein, N.A. (1991). O lovkosti i yeio razvitii [About agility and its development]. Moscow: Phisycal culture and sport [in Russian].

Biekhterev, V.M. (1999). Izbrannye trudy po psihologi lichnosti [Selected works on the psychology of personality]. (Vols. 1-2). Saint Petersburg: Piter [in Russian].

Bogoyavlenskaya, D.B. (1987). Psihologicheskiye osnovy intellektualnoy aktivnosti [Psychological basis of intellectual activity]. Extended abstract of Doctor's thesis. Moscow [in Russian].

Bozhovich, L.I. (1995). Izbrannye pedagogicheskyiee trudy. Problemy formirovaniya lyichnosti [Selected pedagogical studies. The problems of personaliyu forming]. Moscow: Mezhdunar. ped. akadem. [in Russian].

Varenik, E.N., Korlykhanova, Z.A., \& Kitova, E.V. (2009). Fizicheskoye i rechevoye razvitiye doshkolnikov: vzayemodeistviye uchitelya-logopeda i instruktora po fizkulture [Physical and speech development of preschoolers: interaction of speech-therapist and physical culture instructor]. Moscow: TN Sfera [in Russian].

Vasiukova, N.Ye., \& Chekhonina, O.I. (2004). Integraciia soderzhaniia obrazovaniia cherez planirovanie pedagogicheskoj dejatelinosti [Integration of educational content through educational planning.]. Detskiy sad ot $A$ do $Y a-$ Kindergarten from $A$ to $Z, 6(12), 8-14$ [in Russian].

Venher, L.A. (1988). Vospitaniye sensornoy kultury rebyonka [The upbringing of child's sensor culture]. Moscow: Prosveshcheniye [in Russian].

Vilchkovskyi, E.S. (1990). Psikhologo-pedagogicheskiie osnovy sistemy phisicheskogo vospitaniya doshkolnikov. Vospitaniye detey doshkolbogo vozrasta [Psychological and pedagogical basis of the system of physical education of preschoolers]. Kyiv: Radianska shkola [in Ukrainian].

Vygotskiy, L.S. (2003). Psikhologiya razvitiya rebyonka [The psychology of child's development]. Moscow: EKSMO [in Russian].

Galperin, P.Ya., \& Kobylnitskaya, S.L. (1974). Ekspyeryemyentalnoye formirovaniye vnimanyia [Expiremental forming of attention]. Moscow: Moscow University Edition [in Russian].

Giliarovskiy, V.A. (1997). K voprosu o geneze zailaniia u malenkih detej $i$ roli ego dlya obshchego razvitiya lichnosti $i$ ego lecheniie [To the question about genesis of children's stuttering and its role for personality's comprehensive development and its treatment]. (Vols. 1-2). Moscow: VLADOS [in Russian].

Zaporozhets, A.V. (1981). Usloviya $i$ dvizhushchiye prichiny psikhicheskogo razvitiya rebyonka [Conditions and reasons of child's psychological development]. Moscow: Prosveshcheniye [in Russian].

Kalmykova, L.O. (2016). Pro stan rozvytku movlennia yak diialnosti u ditej 5 rokiv [About the state of development of speech as activity in children of 5 years]. Psyholingvistyka - Psycholinguistics, 19(1), 84-97 [in Ukrainian].

Krutsevych, T.Yu., \& Panhelova, N.Ye. (2015). Kontseptualni zasady harmoniinoho rozvytku osobystosti dytyny doshkilnoho viku v protsesi fizychnoho vykhovannia [Conceptual conditions of preschooler harmonious personal development in the process of physical education]. Teoriia $i$ metodyka fizychnoho vykhovannia $i$ sportu - Theory and methodic of physical education and sport, 2, 106-115 [in Ukrainian].

Koltsova, M.M., \& Rudina, M.S. (2004). Rebenok uchitsja govorit. Palchikovyj igrotrening [A child learns to speak. Finger play training]. Yekaterinburg: U-Faktoriya [in Russian]. 
Leontev, A.N. (1999). Deyatelnost i lichnost [Activity and personality]. Samara: Ed. «Bakhrakh» [in Russian].

Luriia, A.R. (2007). Osnovy nejropsihologii [Basics of Neuropsychology]. Moscow: Akademiya [in Russian].

Mastiukova, Ye.M. (1992). Rebionok s otkloneniiami v razvitii: Ranniaia diagnostika $i$ korrektsiia [A child with defections in development: early diagnostic and correction]. Moscow: Prosveshcheniie [in Russian].

Medviedieva, Ye.Yu., \& Yanochkina, P.A. (2018). Ispolzovaniie dvigatelnykh tekhnik $\mathrm{v}$ rabote po korektsii narusheniy zvukoproiznosheniia u detey doshkolnogo vozrasta: neyroosikhologicheskiy aspect [The usage of motor techniques in a correction work with school-age children: neuro-psychological aspect]. Perspektivy nauki i obrazovaniya - Perspectives of science and education, 2(32), 152-155 [in Russian].

Mosaliova, N.V. (2014). Integrirovannye zaniatiia po rechevomu i fizicheskomu razvitiiu detej starshego doshkolnogo vozrasta. "Festival pedagogicheskih idej» Otkrytyj urok [Integrated classes in speech and physical development of children of senior preschool age. "Festival of pedagogical ideas» Open lesson]. Retrieved from http:открытый урок.рф/статьи/59117

Moskalenko, N.V. (2010). Teoretyko-metodychni zasady innovatsiinykh tekhnolohii $\mathrm{v}$ systemi fizychnoho vykhovannia molodshykh shkoliariv [Thearetical and methodic basis of innovative technologies in a system of physical education of younger schoolchildren]. Extended abstract of Doctor's thesis. Dnipropetrovsk [in Ukrainian].

Pavlov, I.P. (1951). Polnoe sobranie sochinenij [Complete Works]. (Vols. 1-4). Moscow [in Russian].

Panhelova, N.Ye. (2014). Formuvannia harmoniino rozvynenoi osobystosti dytyny doshkilnoho viku $\mathrm{v}$ protsesi fizychnoho vykhovannia [The formation of harmoniously developed personality of a preschooler in the process of physical education]. Extended abstract of Doctor's thesis. Pereiaslav-Khmelnytskyi [in Ukrainian].

Pyvovar, A.A. (2005). Poiednanyi rozvytok fizychnykh i piznavalnykh zdibnostei ditei 5 i 6 rokiv u protsesi fizychnoho vykhovannia [Combined development of physical and informative skills of 5-6 years old children in the process of physical education]. Extended abstract of Candidate's thesis. PereiaslavKhmelnytskyi [in Ukrainian].

Poddyakov, N.N. (2006). Dominirovaniye protsessov integratsii - zakon razvitiya detey doshkolnogo vozrasta [The dominance of integrational processes - the law of development of preschoolers]. Doshkolnoe vospytanye - Preschool upbringing, 1, 73-77 [in Russian].

Pozhilenko, Ye.A. (2006). Artikuliatsionnaia gimnastika po razvitiiu motoriki, dyhaniia $i$ golosa detey [Articulation gymnastics for breath and speech development of children]. Moscow: Karo [in Russian].

Polishchuk, V.V. (2008). Rozvytok rukhovykh i rozumovykh zdibnostei ditei 5-ho i 6-ho rokiv zhyttia v protsesi fizychnoho vykhovannia zasobamy doshkilnoho turyzmu [Development of motor and mental skills of 5-6 years old children in the process of physical education by means of preschool tourism]. Extended abstract of Candidate's thesis. Lviv [in Ukrainian].

Propisnova, Ye.P. (2006). Integracija dvigatelnogo i rechovogo razvitiia doshkolnikov (na osnove siuzhetno-rolevoy logoritmicheskoj gimnastiki) [Integration of motor 
and speech development of preschool children (based on plot-role logorithmic gymnastics)]. Nachalnaya shkola plus do i posle - Primary school plus before and after, 7, 11-13 [in Russian].

Rubinshtein, S.L. (1999). Osnovy obshchey psikhologii [General psychology basics]. Saint-Petersburg: Piter Kom [in Russian].

Ryzhova, N.V. (2007). Razvitie rechi v detskom sadu [The development of speech in kindergarten]. Yaroslavl: Akademiia razvitiia [in Russian].

Sechenov, I.M. (1947). Izbrannye filosofskiye $i$ psikhologicheskiye proizvedeniya [Selected philosophical and psychological works]. Moscow [in Russian].

Somkova, O.N. (2012). Novye podhody k organizacii raboty po razvitiju rechi detej doshkolnogo vozrasta [New approaches to the organization of work on the development of speech of preschool children]. Detskij sad : Teorija i praktika Kindergarten: Theory and Practice, 3, 6-7 [in Russian].

Ushakova, O.S., \& Strunina, Ye.M. (2010). Metodika razvitiya rechi detey doshkolnogo vozrasta [The methods of speech development of pre-schoolers]. Moscow: Humanit. izd. tsentr VLADOS [in Russian].

Khrisman, T.P., Yeremieieva, V.D., \& Loskutova, T.D. (1991). Emotsii, rech i aktivnost mozga rebionka [Emotions, speech and activity of a child's brain]. Moscow: Pedagogics [in Russian].

Yadova, R.Kh. (2015). Formirovaniye rechevoy kultury mladshykh doshkolnikov sredstvami fizicheskogo vospitaniya [Speech culture formation of preschoolers by means of physical education]. Extended abstract of Candidate's thesis. Maikop [in Russian].

Colletta, J., Pellenq, C., Hadian-cefidekhanie, A., \& Rousset, I. (2018). Developmental changes in articulation rate and phonic groups during narration in French children aged four to eleven years. Journal of Child Language, 45(6), 1-20. https://doi. org/10.1017/S0305000918000235

Iverson, J. (2010). Developing language in a developing body: The relationship between motor development and language development. Journal of Child Language, 37(2), 229-261. https://doi.org/10.1017/S0305000909990432

Walker, J.F., \& Archibald, L.M. D. (2006). Articulation rate in preschool children: a 3-year longitudinal study. International Journal of Language and Communication Disorders, 41(5), 541-65. https://doi.org/10.1080/10428190500343043

\begin{abstract}
АНОТАЦІЯ
Дослідження присвячене проблемі розвитку мовлення дітей старшого дошкільного віку в процесі виконання рухових дій, потребувало звернення до нейропсихологічних засад активізації мовлення дітей при виконанні рухових дій. Результати досліджень свідчать, що дошкільний вік - це найбільш відповідальний період у становленні особистості людини, їі психологічного і фізичного розвитку, в тому числі - розвитку мовлення. Наявність взаємозв'язку загальної та мовленнєвої моторики доведено у дослідженнях І.П. Павлова, О.М. Леонтьєва, О.Р. Лурія та ін., що обгрунтовує положення про те, що застосування різноманітних рухових дій сприяє вирішенню завдань мовленнєвого розвитку дитини. Наявність взаємозв'язку між інтелектуальним, соціальним, мовленнєвим розвитком і руховою
\end{abstract}


активністю, станом здоров'я дитини визначає доцільність застосування таких підходів, які передбачають інтегрований вплив на особистість дитини. Виключна роль фізичного і мовленнєвого розвитку визначає їх інтеграцію для загального розвитку, соціалізації дитини. Метою інтегрованої мовленнєворухової сумісної діяльності $\epsilon$ забезпечення взаємозв'язку рухової активності й розвитку мовлення дітей дошкільного віку. Впровадження інтегрованого підходу потребує застосування інноваційних технологій, таких як: пальчикова, артикулячійна, дихальна гімнастики; футбол-аеробіка; логоритміка та ін. Для перевірки ефективності інтегрованої мовленнєво-рухової діяльності був проведений експеримент. Досліджуваним контингентом були діти 5-6 років, вихованці закладів дошкільної освіти № 9 "Сонечко» $і$ № 10 "Любавонька» м. Переяслав-Хмельницького Київської області. Після обстеження були отримані дані, які свідчать про позитивну динаміку за усіма показниками мовлення.

Ключові слова: нейропсихологічні засади інтеграція, мовлення, рухова активність, старші дошкільники.

\section{Пангелова Наталия, Круцевич Татьяна. Нейропсихологические основы активизации речи детей старшего дошкольного возраста при выполнении двигательных действий}

\section{АННОТАЦИЯ}

Исследование посвящено проблеме развития речи детей старшего дошкольного возраста в процессе выполнения двигательных действий, что обусловило необходимость обращения $к$ нейропсихологическим основам активизации речи детей в прочессе выполнения двигательных действий. Результаты исследований свидетельствуют, что дошкольный возраст это самый ответственный период в становлении личности человека, его психологического и физического развития, в том числе - развития речи. Наличие взаимосвязи общей и речевой моторики доказано в исследованиях И.П. Павлова, А.Н. Леонтьева, А.Р. Лурия и др., что обосновывает положение о том, что применение различных двигательных действий способствует решению задач речевого развития ребенка. Наличие взаимосвязи между интеллектуальным, социальным, речевым развитием и двигательной активностью, состоянием здоровья ребенка определяет целесообразность применения таких подходов, которые предусматривают интегрированное воздействие на личность ребенка. Исключительная роль фризического и речевого развития определяет их интеграчию для общего развития, социализации ребенка. Целью интегрированной двигательно-речевой совместной деятельности является обеспечение взаимосвязи двигательной активности и развития речи детей дошкольного возраста. Внедрение интегрированного подхода требует применения инновационных технологий, таких как: пальчиковая, артикуляционная, дыхательная гимнастики; футболаэробика; логоритмика и др. Для проверки эффективности интегрированной 
Neuropsychological Principles of Activating the Speech of Children...

двигательно-речевой деятельности был проведен эксперимент. Исследуемым контингентом были дети 5-6 лет, воспитанники учреждений дошкольного образования № 9 "Солнышко» $и$ № 10 "Любавонька» г. ПереяславХмельницкого Киевской области. После обследования были получены данные, свидетельствующие о положительной динамике всех составляющих речи.

Ключевые слова: нейропсихологические основы, интеграция, речь, двигательная активность, старшие дошкольники. 